\title{
Anisakidae in beluga whales Delphinapterus leucas from Hudson Bay and Hudson Strait
}

\author{
Katarzyna Najda ${ }^{1}$, Manon Simard ${ }^{2}$, Julia Osewska ${ }^{1}$, Janina Dziekońska-Rynko ${ }^{3}$, \\ Joanna Dzido ${ }^{1}$, Jerzy Rokicki ${ }^{1, *}$ \\ ${ }^{1}$ Department of Invertebrate Zoology and Parasitology, University of Gdansk, Wita Stwosza 59, 80-308 Gdańsk, Poland \\ ${ }^{2}$ Nunavik Research Centre, Makivik Corporation, PO Box 179, Kuujjuaq, Quebec J0M 1C0, Canada \\ ${ }^{3}$ Department of Zoology, Faculty of Biology and Biotechnology, University of Warmia and Mazury, Oczapowskiego St. 5, \\ 10-719 Olsztyn, Poland
}

\begin{abstract}
A total of 190 nematodes was isolated from the stomachs of 13 beluga whales Delphinapterus leucas from the Arctic part of Hudson Bay and Hudson Strait. Infection intensity ranged from 1 to 57 specimens and prevalence was $84.62 \%$. Morphological examination of the nematodes revealed the presence of 3 species: Pseudoterranova decipiens sensu lato, Contracaecum osculatum s.l., and Anisakis simplex s.l. Molecular analysis by PCR-based restriction fragment length polymorphism (PCR-RFLP) resulted in the identification of 4 species: Pseudoterranova bulbosa, Contracaecum osculatum A and C, and Anisakis simplex sensu stricto. The nematodes were present in 3 developmental stages: L3 (159 specimens), L4 (16 larvae), and adults (15 worms: 11 males and 4 females).
\end{abstract}

KEY WORDS: Anisakis $\cdot$ Contracaecum $\cdot$ Pseudoterranova $\cdot$ Canada $\cdot$ Cetacean $\cdot$ Parasite $\cdot$ Zoonosis Resale or republication not permitted without written consent of the publisher

\section{INTRODUCTION}

The beluga whale Delphinapterus leucas (Pallas, 1776) is a marine mammal that inhabits Arctic and Subarctic waters. Like other marine mammals, the beluga is the definitive host for parasitic nematodes of the family Anisakidae. When ingested by humans, anisakid larvae can cause anisakiasis, which may lead to abdominal pain, nausea and/or diarrhea, and also 'gastroallergic anisakiasis', which presents clinical manifestations ranging from urticaria to lifethreatening anaphylactic shock (Nieuwenhuizen et al. 2006). The anisakid life cycle involves invertebrates (crustaceans), fish as the second intermediate or paratenic host, and nematodes, which reproduce only in marine mammals and birds.

Information on the diet of belugas suggests a potential for helminth infection. Belugas feed mainly on polar cod Boreogadus saida, Arctic cod Arctogadus glacialis, squid (Cephalopoda), lantern fish (Myctophidae), redfish Sebastes spp., and shrimp Pandalus borealis (Heide-Jørgensen \& Teilmann 1994). The Greenland halibut Reinhardtius hippoglossoides is frequently consumed as well, and serves as a host for larvae of Anisakis simplex sensu stricto, Pseudoterranova bulbosa, Contracaecum osculatum A, B, and $\mathrm{C}$, and Hysterothylacium aduncum (Karpiej et al. 2013).

Data on beluga parasites are scarce because of the rarity of specimens and the difficulties involved in obtaining it. Thus far, research on belugas conducted in the Canadian Arctic has yielded records of A. simplex in specimens from the St. Lawrence estuary and/or Gulf of St. Lawrence (Lyster 1940, Vladykov 1944, Martineau et al. 1988), in addition to other helminths reported from the beluga population in Churchill, West Hudson Bay (Doan \& Douglas 1953). Wazura et al. (1986), who published data on parasitic 
nematodes in belugas from the Mackenzie River delta in northeast Canada, recorded A. simplex and Contracaecum sp. in all belugas they examined (10 individuals). Theirs was the first record of Contracaecum sp. in belugas from the Nearctic. Measures et al. (1995), who examined 38 belugas in the St. Lawrence estuary, found Pseudoterranova sp. and Contracaecinea sp. in addition to A. simplex. More recently, Mattiucci \& Nascetti (2007) reported 5 anisakid species from the northwest Atlantic: A. simplex s.s., 2 sibling species of Pseudoterranova decipiens (P. bulbosa and $P$. decipiens s.s.), and 2 sibling species of the C. osculatum complex (C. osculatum A and C). The single beluga those authors examined hosted A. simplex s.s. only. In the eastern Canadian Arctic (from the Inuit region of Nunavik), anisakids of 19 beluga whales were tested as a zoonotic hazard for humans (Pufall et al. 2012).

This work addresses the occurrence of parasitic nematodes in beluga whales that were previously unreported from the east Hudson Bay and Hudson Strait in the Canadian Arctic. An attempt was also made to elucidate anisakid dynamics by analysing the demographic composition of the nematode fauna. Studies on anisakid dynamics in belugas are important because as the final hosts, the whales play a central role in the transmission of these parasites to Crustacea, and subsequently to fish, which are consumed by the Inuit.

\section{MATERIALS AND METHODS}

\section{Parasite materials}

Delphinapterus leucas specimens were obtained between June 2008 and September 2009 from professional whale hunters operating in the northern regions of Quebec (Fig. 1). Due to the temperature and time-dependent constraints as well as available funding, the materials were collected irregularly (seasonally). The hunters were trained in sampling techniques, were provided with organ collecting kits for freezing, and were asked to record the capture site as well as basic data (e.g. sex) on the whales (Table 1). The beluga stomach contents and stomach walls were macroscopically examined in the laboratory for lesions and anisakid parasites. Anisakids from the stomachs of $13 \mathrm{D}$. leucas individuals were isolated and counted. The nematodes were rinsed in deionized water and stored in $70 \%$ ethanol until analysis. All specimens were sectioned into 3 parts. The anterior and posterior parts of the body were stored in $70 \%$ ethanol with $5 \%$ glycerol in open tubes to evaporate the ethanol. After clearing, specimens were examined on slides using a light microscope. Taxonomic identification of the nematodes was based on characteristics described by Fagerholm (1991). Identification of maturity stages was determined through observation of caudal structures, larval tooth, spicule or uterus filled with ovas. The presence of lips surrounding the mouth cavity was also an essential diagnostic feature (Weerasooriya et al. 1986, Grabda-Kazubska \& Okulewicz 2005). The mid-part of the nematode bodies were prepared for molecular identification by fixing in $70 \%$ ethanol.

\section{DNA isolation and amplification}

A random sample of 46 nematode specimens identified morphologically were also subjected to molecular identification through PCR-based restriction fragment length polymorphism (PCR-RFLP), using DNA isolated from the mid-part of the nematode bodies. Genomic DNA was isolated from the nematodes using a procedure described by Hoarau et al. (2002). Amplification of the rDNA ITS1-5.8S-ITS2 region was carried out as described by Zhu et al. (1998). Each reaction mixture (total volume $=16 \mu \mathrm{l}$ ) contained $1 \mu \mathrm{l}$ solution of isolated genomic DNA, $1 \mathrm{U}$ DyNAzyme II DNA Polymerase (Finnzymes), dNTPs (250 $\mu \mathrm{M}$ each), $100 \mu \mathrm{M}$ of each primer (NC2 and NC5; Zhu et al. 1998) and buffer $1 \times(10 \mathrm{mM}$ Tris-HCl

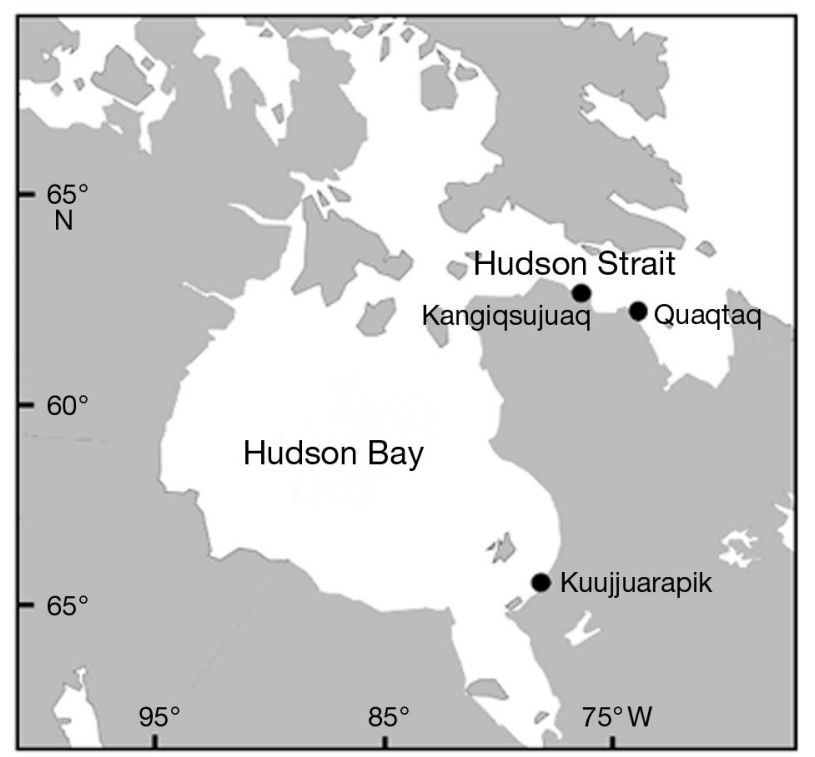

Fig. 1. Beluga whale Delphinapterus leucas collection sites from Hudson Bay and Hudson Strait 
Table 1. Hudson Bay and Strait beluga whale Delphinapterus leucas captures and corresponding anisakid numbers

\begin{tabular}{|c|c|c|c|c|c|c|c|c|c|}
\hline Beluga (DL) & Community & Year & Season & Age & Sex & $\begin{array}{c}\text { No. of } \\
\text { nematodes }\end{array}$ & $\begin{array}{c}\text { Anisakis } \\
\text { simplex s.l. }\end{array}$ & $\begin{array}{l}\text { Contracaecum } \\
\text { osculatum s.l. }\end{array}$ & $\begin{array}{c}\text { Pseudoterranova } \\
\text { decipiens s.l. }\end{array}$ \\
\hline DL-0916 & Kuujjuarapik & 2009 & Summer & - & M & 9 & - & 9 & - \\
\hline DL-0931 & Kangiqsujuaq & 2009 & Summer & - & $\mathrm{F}$ & 57 & 4 & - & 53 \\
\hline DL-0935 & Kangiqsujuaq & 2009 & Summer & - & $\mathrm{F}$ & 50 & 1 & 42 & 7 \\
\hline DL-10001 & Quaqtaq & 2008 & Spring & 41 & $\mathrm{~F}$ & 2 & 2 & - & - \\
\hline DL-10003 & Quaqtaq & 2008 & Spring & 23 & $\mathrm{~F}$ & 38 & 1 & 4 & 33 \\
\hline DL-10006 & Quaqtaq & 2008 & Spring & 13 & $\mathrm{M}$ & 6 & - & 2 & 4 \\
\hline DL-10008 & Quaqtaq & 2008 & Spring & 17 & $\mathrm{~F}$ & 0 & - & - & - \\
\hline DL-10009 & Quaqtaq & 2008 & Spring & 29 & $\mathrm{~F}$ & 8 & - & - & 8 \\
\hline DL-10011 & Quaqtaq & 2008 & Spring & - & $\mathrm{F}$ & 0 & - & - & - \\
\hline DL-10012 & Quaqtaq & 2008 & Spring & 17 & $\mathrm{~F}$ & 2 & - & 2 & - \\
\hline DL-10015 & Quaqtaq & 2008 & Spring & 15 & M & 1 & - & - & 1 \\
\hline DL-10032 & Kuujjuarapik & 2008 & Summer & 13 & M & 6 & - & - & 6 \\
\hline DL-10039 & Kuujjuarapik & 2008 & Fall & - & $\mathrm{F}$ & 11 & - & - & 11 \\
\hline
\end{tabular}

$[\mathrm{pH}=8.4], 50 \mathrm{mM} \mathrm{KCl}, 0.1 \%$ Triton X-100 and $1.5 \mathrm{mM} \mathrm{MgCl}_{2}$ ). Amplification was carried out in a Progene thermocycler (Techne). The cycling protocol involved $5 \mathrm{~min}$ at $94^{\circ} \mathrm{C}, 30$ cycles with $30 \mathrm{~s}$ at $94^{\circ} \mathrm{C}$, $30 \mathrm{~s}$ at $60^{\circ} \mathrm{C}$, and $30 \mathrm{~s}$ at $72^{\circ} \mathrm{C}$, followed by $5 \mathrm{~min}$ at $72^{\circ} \mathrm{C}$. PCR products were separated electrophoretically on $1 \%$ agarose gels and visualized by staining with ethidium bromide.

\section{Restriction fragment length polymorphism}

The amplified DNA samples were digested with RsaI, TaqI, HhaI, and XbaI (Fermentas) restriction enzymes, and the products were separated on $4 \%$ agarose gels and visualized by staining with ethidium bromide (Sambrook et al. 1989). The pUC Mix Marker (0.5 $\mu \mathrm{g}^{-1}$; Marker 8, Fermentas) was used as a marker. Product sizes were compared to rDNA ITS1-5.8S-ITS2 digestion patterns keys (D'Amelio et al. 2000, Kijewska et al. 2002).

\section{Statistical treatment}

Ecological parameters such as prevalence, infection intensity, and abundance were used as recommended by Margolis et al. (1982). All statistical procedures were performed with Statistica v.10.0 (StatSoft). Data from only certain species were subjected to statistical analysis, based on adequate sample sizes. Non-parametric tests (Mann-Whitney $U$-test and Spearman's rank correlation) were used because of the irregular distribution of parasites caused by accumulation of larvae and diet preferences of each beluga.

\section{RESULTS}

Out of the 13 belugas examined, 11 were infected with nematodes at an infection intensity of 1 to 57 individuals. The 190 nematode individuals collected were morphologically identified as Anisakis simplex s.l. (8 ind.), Contracaecum osculatum s.l. (50 ind.), and Pseudoterranova decipiens s.l. (123 ind.). The heaviest infection was observed in beluga DL-09-31, whose nematofauna was dominated by $P$. decipiens s.l. A similarly heavy $P$. decipiens s.l. infection was also found in DL-10003, while the nematofauna of DL-09-35 was dominated by C. osculatum s.l. (Table 2).

The highest prevalence $(61.54 \%)$ and intensity (11.18 specimens) were typical of $P$. decipiens s.l. The lowest indices of infection $(30.77 \%$ prevalence and intensity of 0.72 specimens) were shown by $A$. simplex s.l. (Table 2). The low prevalence was influenced by the small sample size.

Morphological examination revealed the presence of L3 and L4 larvae as well as adults. The most abundant (159 larvae) were L3 larvae, representing all nematode species identified, whereas adults were not as common, and were dominated by females

Table 2. Ecological parameters of beluga whale Delphinapterus leucas $(\mathrm{n}=13$ ) anisakid infection (see Table 1 for parasite names)

\begin{tabular}{|lrrrrr|}
\hline $\begin{array}{l}\text { Anisakid } \\
\text { species }\end{array}$ & $\begin{array}{c}\text { No. of } \\
\text { ind. }\end{array}$ & $\begin{array}{r}\text { Mean } \\
\text { Antensity }\end{array}$ & Range & $\begin{array}{c}\text { Abun- } \\
\text { dance }\end{array}$ & $\begin{array}{c}\text { Prev. } \\
(\%)\end{array}$ \\
\hline $\begin{array}{l}\text { A. simplex } \\
\text { C. osculatum }\end{array}$ & 5 & 0.72 & $1-4$ & 0.62 & 30.77 \\
P. decipiens & 123 & 5.36 & $2-42$ & 4.54 & 38.46 \\
& 11.18 & $1-53$ & 9.46 & 61.54 \\
\hline
\end{tabular}


(Fig. 2). Interestingly, the adults and L4 larvae consisted of $P$. decipiens s.l. only.

Results of the molecular assays (PCR-RFLP) revealed least 4 species of nematodes: 2 belonging to the $C$. osculatum complex, genetically identified as C. osculatum A and C, 1 belonging to the A. simplex complex, genetically identified as A. simplex s.s., and 1 belonging to the $P$. decipiens complex, identified as $P$. bulbosa. As previously mentioned, morphological examination had revealed only 3 species (C. osculatum s.l., A. simplex s.l., and P. decipiens s.l.). All the Canadian Arctic anisakid species identified using molecular assays are sibling species, and are indistinguishable morphologically from other members of the respective complexes. Co-occurrence of sibling C. osculatum species in a single host was not observed.

\section{DISCUSSION}

Anisakid nematodes are cosmopolitan parasites. The toothed and baleen whales are typically parasitised by Anisakis simplex, which has been termed the whale or herring worm. This observation has been confirmed by research on beluga whales Delphinapterus leucas in the Canadian Arctic (Lyster 1940, Vladykov 1944, Doan \& Douglas 1953, Martineau et al. 1988). Parasites of D. leucas had been studied by Wazura et al. (1986), who examined 10 belugas from Mackenzie River and found all of them to be infected by Contracaecum osculatum, 2 of which were also infected by $A$. simplex $\left(<20\right.$ specimens host $\left.{ }^{-1}\right)$. Four of the belugas examined carried $<20$ specimens of $C$. osculatum; 3 hosted 20 to 80 , and the remaining whales yielded $>80$, suggesting that the overall infection level was

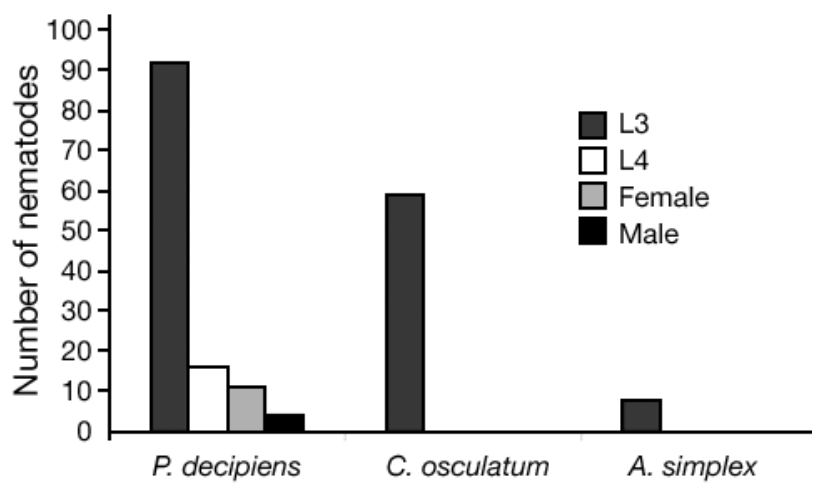

Fig. 2. Number of parasites isolated from beluga whales Delphinapterus leucas, in various stages of development. See Table 1 for parasite genus names much higher than that found in the present study. Interestingly, both Wazura et al. (1986) and the present study found A. simplex (a whale-specific nematode), at much lower abundance and prevalence than $C$. osculatum-a parasite regarded as typical of seals. Moreover, Measures et al. (1995) examined 38 belugas from the St. Lawrence estuary, which yielded not only $A$. simplex (the most prevalent, found in 28 out of 38 belugas) and numerous other parasites, but also Pseudoterranova sp. and Contracaecinea sp. Those authors considered the St. Lawrence estuary beluga to be an accidental host to phocid larval ascaridoids, and suggested that they ingested them with the invertebrate or fish intermediate hosts (Measures et al. 1995). In the present study, belugas from the Hudson Bay and Hudson Strait hosted 4 anisakids: C. osculatum A and C, A. simplex s.s., and the dominant Pseudoterranova bulbosa. To date, belugas from the western part of the Hudson Bay had only been reported to host A. simplex (Doan \& Douglas 1953). This discrepancy may be explained by the fact that there are at least 2 beluga populations in the area: one in the western and other in the eastern part of the Hudson Bay (Brown Gladden et al. 1997), which may differ in behaviour. The populations are migratory and their distribution is partly related to seasonal changes in ice conditions. During the summer, they stay along the Hudson Bay coast, in James and Ungava Bays, while in the winter the populations may mix and potentially interbreed. The winter and spring distribution of Hudson Bay, Ungava Bay and SE Baffin beluga populations aggregate in Hudson Strait, the Labrador Sea and Davis Strait (Donovan 1992). Moreover, the difference between our results of those reported by Doan \& Douglas (1953) may be an outcome of a change in beluga food preferences, or perhaps of variation in species composition of the available food related to continuously changing environmental conditions. There is no doubt, however, that the parasitic infestation of the beluga populations from the western part of the Hudson Bay should be thoroughly investigated.

The proportions of anisakid species found in this study provides evidence that the belugas from Hudson Bay and Hudson Strait are definitive hosts mainly for $P$. decipiens s.l. The nematode fauna observed in these whales probably occurs because they occupy the same habitat as a variety of other marine mammals (including other cetaceans and seals), which can transmit their parasites to the belugas via the food chain. Indeed, the anisakid species shared by seals and belugas indicates that they have similar 
diets. Further evidence is provided by observations of the 2 groups hunting together: in September 1977 , 300 belugas were observed being accompanied by about 65 harp seals, 10 to 20 ringed seals, and 2 or 3 bearded seals (Koski et al. 2002). In addition, belugas are euryphagous, i.e. they have a broad feeding spectrum. They feed on benthic fish (e.g. flatfish, sand lance, and cod), benthic invertebrates (e.g. polychaetes and molluscs), pelagic fish (e.g. capelin, herring, smelt, and salmonids), and pelagic invertebrates (e.g. squid) (Measures et al. 1995). Interestingly, although capelin were uncommon in the stomachs of the Hudson Bay belugas, the stomachs often contained hard parts of invertebrates (e.g. jaws of Nereis and squid beaks), which probably are a food item of considerable importance as noted by Doan \& Douglas (1953). The beluga's habit of feeding near the bottom in the Hudson Bay area was indicated not only by the benthic organisms consumed, but also by the frequent presence of sand and small stones in the animals' stomachs (Doan \& Douglas 1953). This may explain the high numbers of $P$. bulbosa (a species with a benthic life cycle) found in this study, and the different anisakid species composition compared to results from river mouths (Wazura et al. 1986, Measures et al. 1995).

The different proportions of various anisakid developmental stages found in the Canadian Arctic belugas are of interest. Working in the Mackenzie River, Wazura et al. (1986) recorded approximately 80 and $20 \%$ of the parasites to be L3 larvae and adults, respectively. In the St. Lawrence estuary, Measures et al. (1995) found L3 or moulting L3 larvae of Pseudoterranova sp. (in 1 beluga) and Contracaecinea sp. (in 6 belugas). They also observed L3 and L4 (including moulting) larvae and adults (including gravid females) of $A$. simplex s.l. This study showed a higher contribution of adults, representing $P$. decipiens s.l. only. This species was most frequently found, with prevalences of L3, L4, and adults being 83.68, 8.42, and 7.89\%, respectively. Moreover, Pufall et al. (2012) found anisakids at a prevalence of $78.90 \%$ in beluga whales (combining analysis of $A$. simplex and $P$. decipiens from a human health perspective). This prevalence is higher than in our data for those 2 species $(69.23 \%)$.

Interesting was the absence of adult C. osculatum s.l. and A. simplex s.l. The presence of mature individuals of $P$. decipiens s.l. supports the hypothesis that these nematodes attain sexual maturity in belugas. The average lower salinity and higher temperature of the waters of the Mackenzie River delta could be the reason for the observed differences in nema- todes species from the family Anisakidae in this area compared to those from Hudson Bay.

Measures et al. (1995) reported a 17 yr old beluga female carrying the heaviest burden of $A$. simplex s.l. (3158 ind.), but there were no differences in the intensities between stranded female and male belugas. This is consistent with our finding of no difference in intensity of nematodes between sexes (Mann-Whitney $U$-test, $\mathrm{p}>0.05$ ) or ages (Spearman's rank correlation, $\mathrm{p}>0.05$ ).

Belugas have long been a stable food resource for indigenous peoples throughout the Arctic, and continue to be an important part of northern diets today. Off the coast of western Greenland, the beluga is one of the most important marine mammal species harvested, and recent annual catches of between 500 and 1000 belugas have often exceeded the catch of all other whale species combined (Heide-Jørgensen \& Rosing-Asvid 2002). As the definitive hosts for anisakids, belugas play an important role in the transmission of anisakid parasites to fish, which are traditionally consumed raw or prepared in ways that do not kill the larvae, such as smoking or light salting. Therefore, the risk of anisakiasis, a zoonosis caused by L3 anisakid larvae, is considerable. The threat of infection for the human population is exacerbated by the consumption of dried beluga intestines, which may contain anisakid larvae. It is therefore important that the occurrence of anisakid nematodes in belugas be monitored, as a high anisakid prevalence in definitive hosts can potentially contribute to stronger infection rates in fish. Therefore, all the Canadian Arctic beluga populations should be examined to provide baseline data for future comparisons, and for a better understanding of their role in the environment.

Acknowledgements. This study was partially supported by the National Science Centre grant No. DEC-2011/01/B/ NZ8/04194 and by the European Social Fund as a part of the project 'Educators for the elite-integrated training program for PhD students, post-docs and professors as academic teachers at University of Gdansk' within the framework of Human Capital Operational Programme, Action IV.

\section{LITERATURE CITED}

Brown Gladden JG, Ferguson MM, Clayton JW (1997) Matriarchal genetic population structure of North American beluga whales Delphinapterus leucas (Cetacea: Monodontidae). Mol Ecol 6:1033-1046

> D'Amelio S, Mathiopoulos KD, Santos CP, Pugachev ON, Webb SC, Picanco M, Paggi L (2000) Genetic markers in ribosomal DNA for the identification of members of the genus Anisakis (Nematoda: Ascaridoidea) defined by polymerase chain reaction-based restriction fragment 
length polymorphism. Int J Parasitol 30:223-226

Doan KH, Douglas CW (1953) Beluga of the Churchill Region of Hudson Bay. Bull Fish Res Board Can 98:1-27

Donovan GP (1992) Report of the sub-committee on small cetaceans. Rep Int Whal Commn 42:178-234

Fagerholm HP (1991) Systematic implications of male caudal morphology in ascaridoid nematode parasites. Syst Parasitol 19:215-228

Grabda-Kazubska B, Okulewicz A (2005) Pasożyty ryb Polski (klucze do oznaczania-Nicienie (Nematoda). PTP, Warszawa

Heide-Jørgensen MP, Teilmann J (1994) Growth, reproduction, age structure and feeding habits of white whales (Delphinapterus leucas) in West Greenland waters. Medd Grùn Biosci 39:195-212

Heide-Jørgensen MP, Rosing-Asvid A (2002) Catch statistics for belugas in West Greenland 1862 to 1999. NAMMCO Sci Publ 4:127-142

Hoarau G, Holla S, Lescasse R, Stam WT, Olsen JL (2002) Heteroplasmy and evidence for recombination in the mitochondrial control region of the flatfish Platichthys flesus. Mol Biol Evol 19:2261-2264

Karpiej K, Dzido J, Rokicki J, Kijewska A (2013) Anisakid nematodes of Greenland halibut Reinhardtius hippoglossoides from the Barents Sea. J Parasitol 99: 650-654

Kijewska A, Rokicki J, Sitko J, W grzyn G (2002) Ascaridoidea: a simple DNA assay for identification of 11 species infecting marine and freshwater fish, mammals, and fish-eating birds. Exp Parasitol 101:35-39

Koski WR, Davis RA, Finley KJ (2002) Distribution and abundance of Canadian High Arctic belugas, 1974-1979. NAMMCO Sci Publ 4:87-126

Lyster LL (1940) Parasites of some Canadian sea mammals. Can J Res 18d:395-409

Margolis L, Esch GW, Holmes JM, Kuris AM, Shad GA (1982) The use of ecological terms. J Parasitol 68: 131-133

Editorial responsibility: Michael Moore, Woods Hole, Massachusetts, USA
Martineau D, Lagace A, Beland P, Higgins R, Armstrong D, Shugart LR (1988) Pathology of stranded beluga whales (Delphinapterus leucas) from the St. Lawrence Estuary, Quebec, Canada. J Comp Pathol 98:287-311

> Mattiucci S, Nascetti G (2007) Genetic diversity and infection levels of anisakid nematodes parasitic in fish and marine mammals from Boreal and Austral hemispheres. Vet Parasitol 148:43-57

Measures LN, Beland P, Martineau D, De Guise S (1995) Helminths of an endangered population of belugas, Delphinapterus leucas, in the St. Lawrence estuary, Canada. Can J Zool 73:1402-1409

Nieuwenhuizen N, Lopata AL, Jeebhay MF, Herbert DR, Robins TG, Brombacher F (2006) Exposure to the fish parasite Anisakis causes allergic airway hyperreactivity and dermatitis. J Allergy Clin Immunol 117:1098-1105

$>$ Pufall EL, Jones-Bitton A, McEwen SA, Brown TM and others (2012) Prevalence of zoonotic anisakid nematodes in Inuit-harvested fish and mammals from the eastern Canadian Arctic. Foodborne Pathog Dis 9:1002-1009

Sambrook J, Fritsch EF, Maniatis T (1989) Molecular cloning: a laboratory manual. Cold Spring Harbor Laboratory Press, New York, NY

Vladykov VD (1944) Etudes sur les mammifères aquatiques. III. Chasse, biologie, et valeur économique du marsouin blanc ou béluga (Delphinapterus leucas) du fleuve et du golfe Saint-Laurent. Contrib Dep Fish Que 14:1-194

- Wazura KW, Strong JT, Glenn CL, Bush AO (1986) Helminths of the beluga whale from the Mackenzie River Delta, Northwest Territories. J Wildl Dis 22:440-442

Weerasooriya MV, Fujipo T, Ishii Y, Kagei N (1986) The value of external morphology in the identification of larval anisakid nematodes: a scanning electron microscope study. Z Parasitenkd 72:765-778

$>$ Zhu XQ, Gasser RB, Podolska M, Chilton NB (1998) Characterisation of anisakid nematodes with zoonotic potential by nuclear ribosomal DNA sequences. Int J Parasitol 28: 1911-1921

Submitted: December 15, 2014; Accepted: May 4, 2015 Proofs received from author(s): June 12, 2015 